\title{
Heterotrophic plate counts and the isolation of bacteria from mineral waters on selective and enrichment media
}

\author{
Célia M. Manala, Olga C. Nunes, Paula V. Morais \& M.S. da \\ Costa * Centro de Biologia Celular, Departamento de Zoologia and Instituto de \\ Investigação da Água, Universidade de Coimbra, 3049 Coimbra Codex, Portugal
}

Accepted 14 May 1990

\begin{abstract}
Manala, C.M., Nunes, O.C., Morais, P.V. \& da Costa, M.S. 1990. Heterotrophic plate counts and the isolation of bacteria from mineral waters on selective and enrichment media. Journal of Applied Bacteriology 69, 871-876.

The heterotrophic plate counts of 15 brands of bottled non-carbonated mineral waters were examined and found to be generally high and variable. Four selective or enrichment media for the enumeration of coliforms ( $m$-Endo LES and m-lauryl sulphate agar) and Pseudomonas aeruginosa (cetrimide-nalidixic acid agar and malachite green broth) were used to isolate several species of Gram-negative bacteria. Strains identified as CDC gr IVc-2 and Comamonas $(P s$.$) acidovorans were the two$ most commonly isolated. Considerable variation in populations was seen between the brands, as well as between two batches of the same mineral water.
\end{abstract}

Bottled non-carbonated mineral waters generally have high heterotrophic plate counts (HPC), since the elimination of micro-organisms by disinfection or sterilization is not permitted (Anon. 1980). Limits for the $\mathrm{HPC}$ at $22^{\circ} \mathrm{C}$ and $37^{\circ} \mathrm{C}$ apply only to bottles stored at $4^{\circ} \mathrm{C}$ for 12 hours after bottling. There are strict standards, however, that prohibit the sale of mineral waters containing coliforms, faecal coliforms, faecal streptococci, sulphide-reducing clostridial sporeformers, Pseudomonas aeruginosa, and pathogens (Anon. 1980).

The bacterial populations of mineral waters are diverse, and brand-dependent. These populations often include species of Pseudomonas, Achromobacter, Alcaligenes, Acinetobacter, Flavobacterium, Aeromonas, Caulobacter, Arthrobacter, Corynebacterium and sometimes iron bacteria (Gonzalez et al. 1987). Most studies indicate, but do not conclusively show that the bacteria in bottled mineral waters are derived from strains present in the source water in low numbers, and which grow in the bottles (Schmidt-Lorenz 1976).

\footnotetext{
* Corresponding author.
}

There is concern that the growth of HPC bacteria could interfere with the detection of small numbers of faecal indicators (Geldreich et al. 1975), which may also occasionally produce atypical colonies on isolation media. Nonpigmented $P$ s. aeruginosa strains have also been found by special investigations (Havelaar et al. 1985). These would have been missed by routine examination techniques. It has also been noted that some quality control laboratories incubate cultures for the enumeration of coliforms or faecal coliforms for $48 \mathrm{~h}$, instead of the 'standard' $24 \mathrm{~h}$, in an attempt to recover stressed organisms. This has resulted in false-positive 'presumptive coliforms' and temporary refusal of permission for sale of batches.

In this study the heterotrophic plate counts of 15 brands of bottled mineral water were compared. Random colonies from $\mathrm{m}$-Endo LES and m-Lauryl sulphate agar (m-LSA) used for enumeration of coliforms in drinking water (Anon. $1982,1985)$ and centrimide-nalidixic acid agar (CNA) and malachite green enrichment broth (MGB) used for the enumeration of Ps. aeruginosa (Shubert \& Blum 1974; Cian \& Devoucoux 1981) were isolated to assess the occurrence of 
atypical colonies, as well as to identify other mineral water bacteria capable of growth on these media.

\section{Methods and Materials}

\section{SAM PLES}

Fifteen brands of non-carbonated mineral waters were examined (Table 1). Thirteen were purchased at retail outlets in Portugal, France (F, O, P) and Belgium (L). Mineral water D was packaged in 0.81 returnable glass bottles, water $\mathrm{N}$ was packaged in 11 Tetrabrik containers, and the remainder in polyvinylchloride (PVC) 1.51 bottles. Two brands, B and J, had been removed from sale because they contained Ps. aeruginosa. Where possible, two batches were examined at intervals of 2-4 months. Each sample consisted of three bottles with the same expiry date or bottling code on the label.

\section{ENUMERATION, ISOLATION AND \\ IDENTIFICATION OF STRAINS}

Heterotrophic plate counts (HPC) of water samples and decimal dilutions thereof were made in duplicate by the pour plate method on plate count agar (PCA) at $37^{\circ} \mathrm{C}$ for $48 \mathrm{~h}$, and at $22^{\circ} \mathrm{C}$ for $72 \mathrm{~h}$ (Anon. 1982; Anon. 1985). Samples, $25 \mathrm{ml}$ and $250 \mathrm{ml}$, were also filtered in duplicate through Gelman type GN-6 $(0.45 \mu \mathrm{m}$ pore size, $47 \mathrm{~mm}$ diameter) membrane filters, washed with phosphate dilution water (Anon. 1985) and placed on m-Endo LES (Difco), $\mathrm{m}$-LSA and CNA (Institute Pasteur) media, and into $50 \mathrm{ml}$ of MGB in $100 \mathrm{ml}$ wide-mouth screw-capped bottles. The plates and bottles were incubated for up to $48 \mathrm{~h}$ at $37^{\circ} \mathrm{C}$. Several colonies with different morphologies were taken from each filter, or in the case of MGB, after transferring a loopful of turbid cultures to PCA and incubating at $37^{\circ} \mathrm{C}$ for $24 \mathrm{~h}$. After purification, the bacteria were stored at $-80^{\circ} \mathrm{C}$ in Nutrient Broth (Difco) containing 15\% glycerol.

All strains were initially screened by Gram stain, cytochrome oxidase test (Gerhardt et al. 1981), and identified with the API 20NE Test System for non-fermenters or the API 20E for fermentative bacteria (API System, S.A., La Balme les Grottes, France) according to manufacturers' instructions. Additional tests included flagella staining (Kodaka et al. 1982), pigment

Table 1. Heterotrophic plate counts (HPC) at $22^{\circ} \mathrm{C}$ and $37^{\circ} \mathrm{C}$ of bottled non-carbonated mineral water.

\begin{tabular}{|c|c|c|c|}
\hline \multirow[b]{2}{*}{ Brand } & \multirow[b]{2}{*}{ Lot } & \multicolumn{2}{|c|}{ Heterotrophic plate count $(\mathrm{cfu} / \mathrm{ml})^{*}$} \\
\hline & & $22^{\circ} \mathrm{C}$ & $37^{\circ} \mathrm{C}$ \\
\hline \multirow[t]{2}{*}{ A } & 1 & $1.5 \times 10^{4} \pm 3.4 \times 10^{3}$ & $4.9 \times 10^{3} \pm 4.9 \times 10^{3}$ \\
\hline & 2 & $1.9 \times 10^{3} \pm 8.5 \times 10^{2}$ & $1.6 \times 10^{2} \pm 8.4 \times 10^{1}$ \\
\hline B & 1 & $3.4 \times 10^{3} \pm 1.2 \times 10^{3}$ & $8.3 \times 10^{2} \pm 8.9 \times 10^{2}$ \\
\hline \multirow[t]{2}{*}{ C } & $i$ & $7.8 \times 10^{3} \pm 2.7 \times 10^{3}$ & $5.5 \times 10^{1} \pm 5.0 \times 10^{1}$ \\
\hline & 2 & $3.9 \times 10^{2} \pm 4.8 \times 10^{2}$ & $7.4 \times 10^{1} \pm 4.0 \times 10^{1}$ \\
\hline \multirow[t]{2}{*}{ D } & 1 & 0 & 0 \\
\hline & 2 & 0 & 0 \\
\hline $\mathbf{F}$ & 1 & $6.7 \times 10^{1} \pm 3.0 \times 10^{1}$ & N.D. \\
\hline $\mathbf{F}$ & 1 & $5.3 \times 10^{3} \pm 4.7 \times 10^{3}$ & $5.2 \times 10^{2} \pm 1.7 \times 10^{2}$ \\
\hline \multirow[t]{2}{*}{ G } & 1 & $2.0 \times 10^{4} \pm 3 \cdot 1 \times 10^{3}$ & $8.8 \times 10^{3} \pm 1.5 \times 10^{3}$ \\
\hline & 2 & $8.3 \times 10^{3} \pm 1.9 \times 10^{3}$ & $1.2 \times 10^{3} \pm 6.2 \times 10^{2}$ \\
\hline \multirow[t]{2}{*}{$\mathbf{H}$} & 1 & $1.4 \times 10^{4} \pm 6.1 \times 10^{3}$ & $5.7 \times 10^{3} \pm 4.0 \times 10^{3}$ \\
\hline & 2 & $2.5 \times 10^{4} \pm 9.0 \times 10^{3}$ & $1.1 \times 10^{4} \pm 3.1 \times 10^{3}$ \\
\hline \multirow[t]{2}{*}{ I } & 1 & $9.1 \times 10^{3} \pm 5.9 \times 10^{3}$ & $1.4 \times 10^{3} \pm 8.0 \times 10^{2}$ \\
\hline & 2 & $1.4 \times 10^{3} \pm 1.0 \times 10^{2}$ & $6.9 \times 10^{3} \pm 1.1 \times 10^{3}$ \\
\hline $\mathbf{J}$ & 1 & $1.9 \times 10^{4} \pm 3.4 \times 10^{3}$ & $6.6 \times 10^{3} \pm 7.4 \times 10^{3}$ \\
\hline $\mathrm{L}$ & 1 & $8 \cdot 0 \pm 0.0$ & $1.2 \times 10^{1} \pm 4.9$ \\
\hline \multirow[t]{2}{*}{$\mathbf{M}$} & 1 & $1.1 \times 10^{4} \pm 7.4 \times 10^{3}$ & $1.0 \times 10^{4} \pm 9.2 \times 10^{3}$ \\
\hline & 2 & $2.6 \times 10^{4} \pm 1.9 \times 10^{4}$ & $5.4 \times 10^{4} \pm 5.3 \times 10^{3}$ \\
\hline \multirow[t]{2}{*}{$\mathbf{N}$} & 1 & 0 & 0 \\
\hline & 2 & 0 & 0 \\
\hline $\mathrm{O}$ & 1 & $5.1 \times 10^{3} \pm 7.4 \times 10^{2}$ & $1.1 \times 10^{3} \pm 1.2 \times 10^{2}$ \\
\hline $\mathbf{P}$ & 1 & $3.6 \times 10^{4} \pm 9.9 \times 10^{3}$ & $2.3 \times 10^{4} \pm 1.6 \times 10^{4}$ \\
\hline
\end{tabular}

* Values are the mean of 3 bottles \pm standard deviation, N.D. not determined. 
production on Pseudo $\mathrm{P}$ and Pseudo $\mathbf{F}$ media (Difco) after incubation at $22^{\circ} \mathrm{C}$ for $10 \mathrm{~d}$, growth in nutrient broth at $41.5^{\circ} \mathrm{C}$ for $24 \mathrm{~h}$, lecithinase production, and growth in $6.5 \% \mathrm{NaCl}$ (Gilardi 1971), hydrolysis of Tween 80 , acetamide hydrolysis, and the presence of poly- $\beta$-hydroxybutyrate inclusions (Gerhardt et al. 1981) after growth in Palleroni \& Doudoroff (1972) medium. Reference strains for these tests, obtained from the American Type Culture Collection (Rockville, Md. USA), were Pseudomonas aeruginosa (ATCC 10145t), Ps. cepacia (ATCC 25416'), Ps. fluorescens (ATCC 13525'), Ps. maltophilia (ATCC 13637'), Acinetobacter calcoaceticus (ATCC 23055', ATCC 9957) and Aeromonas hydrophila (ATCC 7965).

\section{Results}

HETEROTROPHIC PLATE COUNTS OF BOTTLED NON-CARBONATED

MINERAL WATERS

The non-carbonated mineral waters showed a wide variation in heterotrophic plate counts (Table 1). Two waters, one bottled in glass (D) and the other in Tetabrik containers (N) exhibited no recoverable heterotrophic bacteria in both batches tested; all other brands gave $\mathrm{HPC}$ ranging from $0.8 \times 10^{1}$ to $3.6 \times 10^{4}$ colony forming units $(\mathrm{cfu}) / \mathrm{ml}$ at $22^{\circ} \mathrm{C}$ and
$1.1 \times 10^{1}$ to $5.4 \times 10^{4} \mathrm{cfu} / \mathrm{ml}$ at $37^{\circ} \mathrm{C}$. In most cases there were large differences in the heterotrophic plate counts between replicates of each batch, as well as between batches of the same brand (Table 1).

\section{IDENTIFICATION OF STRAINS FROM SELECTIVE AND ENRICHMENT MEDIA}

The 317 strains isolated from the selective or enrichment media were all Gram-negative and with the exception of two strains, all were oxidase positive (Table 2). No bacteria were isolated from brand $F$ irrespective of the selective or enrichment medium used.

Most strains were isolated on several media, although some organisms were consistently isolated from one medium alone: Comamonas ( $P$ s. testosteroni was isolated on m-Endo LES, $F$. meningosepticum and Ps. paucimobilis on CNA, and Ps. alcaligenes and Acinetobacter spp. on $\mathrm{m}$-LSA. Typical coliform colonies were not detected on m-Endo LES or m-LSA. One atypical strain was isolated from m-LSA and identified as Enterobacter agglomerans.

The most abundant bacteria were found in both batches of each brand (Table 3). The most frequently isolated organisms were Centers for Disease Control (CDC) group IVc-2 strains and Comamonas (Ps.) acidovorans. Some strains were isolated only once; Aeromonas hydrophila, E.

Table 2. Isolation of strains from bottled mineral waters on the four selective or enrichment media

\begin{tabular}{|c|c|c|c|c|c|}
\hline \multirow[b]{2}{*}{ Strains } & \multicolumn{5}{|c|}{ No. of strains } \\
\hline & CNA* $^{*}$ & MGB & m-Endo LES & m-LSA & Total \\
\hline Acinetobacter sp. & 0 & 0 & 0 & 3 & 3 \\
\hline Aeromonas hydrophila & 0 & 0 & 1 & 0 & 1 \\
\hline Alcaligenes denitrificans subsp. dentrificans & 1 & 2 & 9 & 15 & 27 \\
\hline dentrificans subsp. xylosoxidans & 0 & 1 & 3 & 2 & 6 \\
\hline CDC gr IV c-2 & 0 & 7 & 9 & 42 & 58 \\
\hline Comamonas (Ps.) acidovorans & 0 & 3 & 23 & 9 & 35 \\
\hline testosteroni & 0 & 0 & 8 & 0 & 8 \\
\hline Enterobacter agglomerans & 0 & 0 & 0 & 1 & 1 \\
\hline Flavobacterium meningosepticum & 2 & 0 & 0 & 0 & 2 \\
\hline Hafnia alvei & 0 & 1 & 0 & 0 & 1 \\
\hline Psetudomonas aeruginosa & 10 & 6 & 15 & 14 & 45 \\
\hline alcaligenes & 0 & 0 & 0 & 11 & 11 \\
\hline cepacia & 1 & 1 & 1 & 1 & 4 \\
\hline fluorescens & 15 & 2 & 1 & 7 & 25 \\
\hline maltophilia & 0 & 0 & 5 & 2 & 7 \\
\hline paucimobilis & 3 & 0 & 0 & 0 & 3 \\
\hline pickettii & 3 & 0 & 9 & 13 & 25 \\
\hline putida & 2 & 0 & 4 & 5 & 11 \\
\hline stutzeri & 2 & 5 & 9 & 8 & 24 \\
\hline Not identified & 0 & 0 & 0 & 4 & 4 \\
\hline
\end{tabular}

* CNA, cetrimide-nalidixic acid agar; MGB, malachite green broth; m-LSA, membrane-lauryl sulphate agar. 


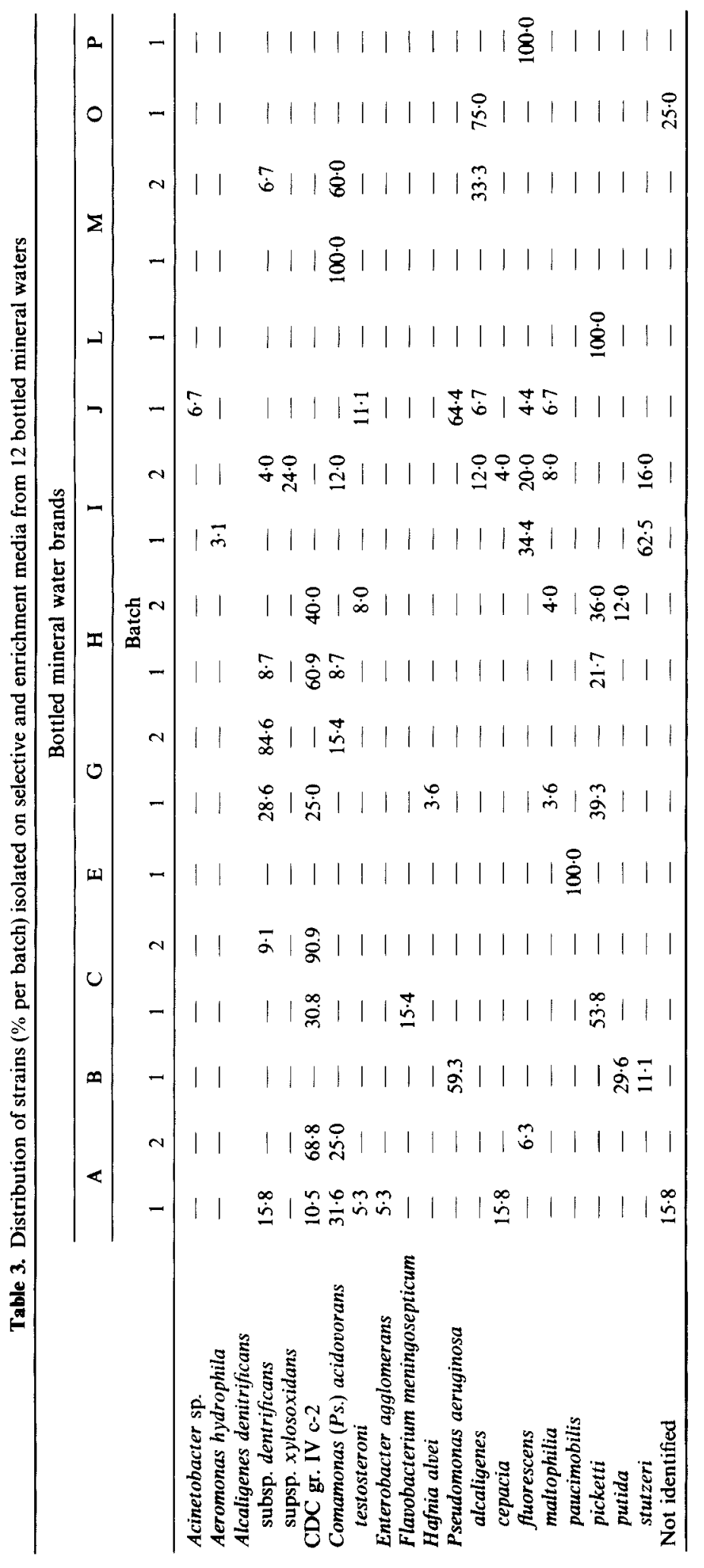


agglomerans, Hafnia alvei and F. meningosepticum.

Usually, several species were found in each brand of water, but $P$ s. paucimobilis, Ps. pickettii and $P$ s. fluorescens were the only bacteria isolated from brands $\mathrm{E}, \mathrm{L}$ and $\mathrm{P}$.

The two brands removed from sale because of the presence of $P$ s. aeruginosa also contained other bacteria. All Ps. aeruginosa strains produced pyocyanin and pyoverdin, easily recognized on CNA because of the bluish-green pigment; MGB, on the other hand, gave high proportions of false positive presumptive results (73\% of the samples) based on turbidity of cultures rather than on pigmentation.

\section{Discussion}

The bottled non-carbonated mineral waters examined in this study gave HPCs comparable to those reported in other studies (Warburton $e t$ al. 1986; Gonzalez et al. 1987; Oger et al. 1987). High numbers of heterotrophic bacteria in noncarbonated mineral waters are considered to be the result of a natural biological process resulting primarily from the multiplication of those bacteria that were present in low numbers in the source water, although sometimes contamination within the bottling plant is considered to be responsible. The absence of recoverable heterotrophic bacteria may suggest the addition of bactericidal agents, such as silver ions. This may explain our failure to recover bacteria from brands $\mathrm{D}$ and $\mathrm{N}$.

Previous studies have shown that media for the enumeration of coliforms also recover minor components of the heterotrophic flora which are not recovered in the HPC tests because of the large numbers of other common bacteria (Duquino \& Rosenberg 1987). In the present study, four media for the enumeration of coliform bacteria and Ps. aeruginosa facilitated the isolation of several bacterial species, primarily pseudomonads. Most of the organisms we isolated have been found previously in other studies on bottled mineral waters, or at their sources. In some cases, species such as Ps. fluorescens, Ps. stutzeri, Ps. alcaligenes and Ps. maltophilia are the major components (QuevedoSarmiento et al. 1986). Others, such as CDC group IVc-2, have not so far been reported in bottled mineral waters. These strains are similar to strains of Bordetella bronchiseptica and share several diagnostic biochemical characteristics, but appear to be unrelated (Oberhofer 1985; Pickett \& Greenwood 1986; Weaver et al. 1983).

The isolation of the same bacterium from two batches of a brand suggests that some species are consistently present for several months in the source or in the bottling plant. Other species were found only in one batch, suggestive of contamination during bottling, but some of these were found in low numbers and may have been missed in the other batch tested. Enterobacter agglomerans was isolated from a random selection of colonies on m-LSA. This would make the water unsuitable for consumption according to the EC directive (Anon. 1980) but failure to recover it in the routine tests for coliforms would not alert suppliers to possible contamination. Previous studies have occasionally reported coliforms (Warburton et al. 1986) and Ps. aeruginosa (Rivilla \& Gonzalez 1988) in small numbers in bottled waters.

The isolation of Ps. aeruginosa in two brands was expected as it was known that these brands had been removed from sale for that reason. Nonetheless their presence, as well as the presence of coliforms in low numbers in some bottled mineral waters, reinforces the value for continued monitoring of mineral waters for evidence of contamination at the source or during the bottling process.

Current legislation is adequate for the examination of indicator bacteria and Ps. aeruginosa in bottled mineral water (Anon. 1980). The media utilized for the examination of the microbiological quality varies, and some may not be adequate, especially if the heterotrophic bacteria are numerous. In this study malachite green broth gave a high percentage of false-positive presumptive tests. These would have to be confirmed during routine work, leading to added costs.

The $P$ s. aeruginosa strains isolated in this study were all pigmented and easily recognized on CNA. Non-pigmented strains have been isolated (Havelaar et al. 1985) and can be missed. Care must be taken to confirm the strains which grow on selective media but lack pigmentation.

Selective or enrichment media may aid the isolation of minor population components which cannot be detected because of large numbers of other heterotrophic bacteria in noncarbonated mineral waters. 
This work was supported in part by the Sociedade das Água de Luso, S.A. and JNICT (43/INF/87). We also wish to thank the assistance of Mr David Coimbra, Ms Isabel Costa and $\mathrm{Mr}$ Miguel Carvalho.

\section{References}

ANON. 1980 Directive du Conseil du 15 Juillet 1980 relative au rapprochement des legislation des États membres concernant l'exploitation et mise dans le commerce des eaux minerales naturelles. (80/777/ CEE) Journal Officiel des Communautes Européennes. No. L229/1-10.

ANON. 1982 The Bacteriological Examination of Drinking Water Supplies 1982. Reports on Public Health and Medical Subjects No. 71. London: HMSO.

ANON. 1985 Standard Methods for the Examination of Water and Wastewater, 16th edn, pp. 853-917. Washington, DC: American Public Health Association.

Cian, L. \& Devoucoux, J. 1981 Recherche de Pseudomonas aeruginosa dans l'eau: methodologie et application à l'analyse bacteriologique des eaux de rivière. Journal Français d'Hydrologie 12, 195-212.

DuQuino, H.H. \& RosenberG, F.A. 1987. Antibioticresistant Pseudomonas in bottled drinking water. Canadian Journal of Microbiology 33, 286-289.

Geldreich, E.E., Nash, H.D., Reasoner, D.J. \& TAYLOR, R.H. 1975 The necessity of controlling bacterial populations in potable waters-bottled water and emergency water supplies. Journal of the American Water Works Association 67, 117-124.

Germardt, P., Murray, R., Costilow, R., Nester, E. Wood, W., Krieg, N. \& Phillips, G. 1981 Manual of Methods for General Bacteriology. Washington, DC: American Society of Microbiology.

Gilard, G.L. 1971 Characterization of nonfermentative nonfastidious Gram negative bacteria encountered in medical bacteriology. Journal of Applied Bacteriology 34, 623-644.

Gonzalez, C., Gutierrez, C. \& Grande, T. 1987 Bacterial flora in bottled uncarbonated mineral drinking water. Canadian Journal of Microbiology 33, $1120-1125$.

HavelaAr, A.H., During, M. \& Delfgou-Van Asch, E.H.M. 1985 Comparative study of membrane filtration and enrichment media for the isolation and enumeration of Pseudomonas aeruginosa from sewage, surface water and swimming pools. Canadian Journal of Microbiology 31, 686-692.

Kodaka, H., ARMFIELd, A.Y., Lombard, G.L. \& Dowell, V.R. 1982 Practical procedure for demonstrating bacterial flagella. Journal of Clinical Microbiology 15, 1044-1048.

Oger, C., Hernandez, J.F., Delattre, J.M., DelabRoISE, A.H. \& KRUPSKY, S. 1987 Étude par epifluorescence de l'evolution de la microflore totale dans une eau minerale enbouteillée. Water Research 4, 469-474.

OBERHOFER, T.R. 1985 Manual of Nonfermenting Fermentative Gram-negative Bacteria. New York: John Wiley.

Palleroni, N.J. \& Doudoroff, M. 1972 Some properties and taxonomic subdivisions of the genus Pseudomonas. Annual Review of Phytopathology 10, $73-100$.

Pickett, M.J. \& Greenwood, J.R. 1986 Identification of oxidase-positive, glucose-negative, motile species of nonfermentative bacilli. Journal of Clinical Microbiology 23, 920-923.

Quevedo-Sarmiento, J., Ramos-CoRmenzana, A. \& GonZalez-LoPEZ, J. 1986 Isolation and characterization of aerobic heterotrophic bacteria from natural spring waters in the Lanjaron area (Spain). Journal of Applied Bacteriology 61, 365-372.

Rivilla, R. \& Gonzalez, C. 1988 Simplified methods for the microbiological evaluation of bottled natural mineral waters. Journal of Applied Bacteriology 64, 273-278.

SChubert, R. \& Blum, U. 1974 Zur Frage der Eignung der Malachitgrün-Bouillon nach Habs und Kirchner als Anreicherungs-medium für Pseudomonas aeruginosa aus dem Wasser. Zentralblatt für Bakteriologie Mikrobiologie und Hygiene Abt. I. Orig. B 158, 583-587.

SCHMIDT-LORENZ, W. 1976 Microbiological characteristics of natural mineral water. Annales Institut Superior di Sanita 12, 93-112.

Warburton, D.W., Peterkin, P.I., Weiss, K.F. \& JOHNSON, M.A. 1986 Microbiological quality of bottled water sold in Canada. Canadian Journal of Microbiology 32, 891-893.

Weaver, R.E., Hollis, W.A., Clark, W.A. \& Riley, P. 1983 The Identification of Unusual Gram-negative Bacterial, pp. 1-12. Atlanta: Centers for Disease Control. 